\title{
A Regional Scale Evaluation of Conservation Status of Orchid Species Recorded in The Eastern Mediterranean Region of Turkey
}

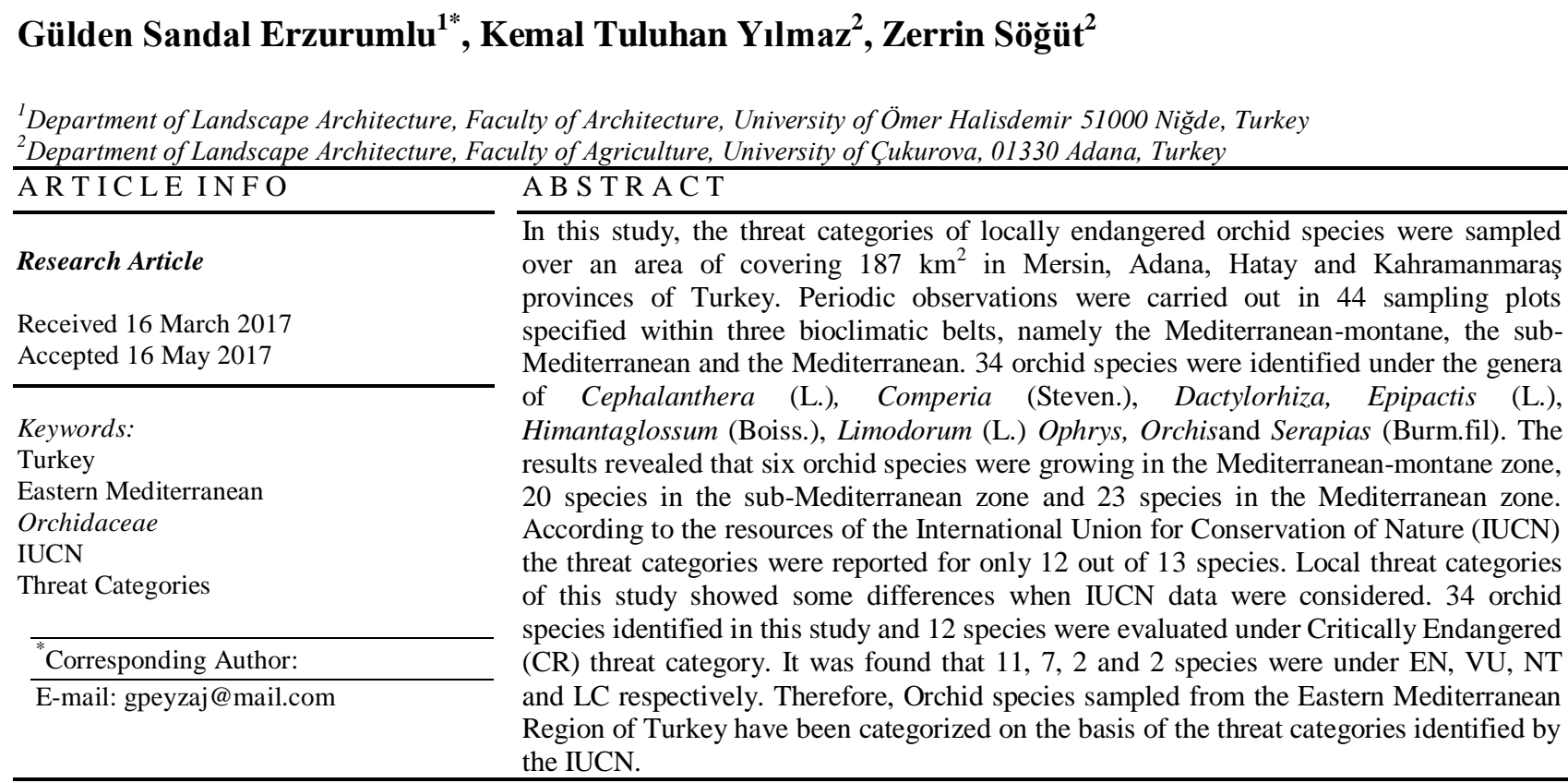

DOI: https://doi.org/10.24925/turjaf.v5i9.999-1001.1233

\section{Introduction}

Orchidaceae is the largest and most diverse family of flowering plants. Although there are various studies on its taxonomy, it was reported that only 900 genera and 20 000 species were identified within the orchidaceae family (Horak, 2004).

It was precisely reported that, in Turkey, totally 49 out of 204 orchid species are hybrid grown and belongs to 23 genera (IUCN, 2008). Seventy-five species found in the Eastern Mediterranean Region constitute $36.8 \%$ of the total orchid species.

In Turkey, only a few studies have been conducted to assess the conservation status of plant biodiversity on a regional scale. These regions included Çukurova Deltas (The Ceyhan Delta and the Seyhan Delta) located in the southern coast of Turkey and have a quite high biological diversity with 600 plant taxa (Çakan et al., 2005).

Kazdağı National Park within the provincial border of Balikesir, has 21 plant taxa from Orchidaceae family were reported by the national database. Epipactis pontica within these taxa was mentioned as an endemic species of the country.

Several researchers studied Ophrys and Orchis species from Turkey as well. For example, Yeşilyurt and Akaydın (2012) carried out study to identify the endemic flora of Muğla province (Western Mediterranean region of
Turkey). The endemic plant species list of Muğla province was listed according to the Flora of Turkey. Most of the Ophrys, Orchis and the endemic species (namely, Ophry sargolica H.Fleischm. (CR), O. calypsus M. (CR), O. holoserica (Burm.fil.) (VU), O. homeri M. (CR), O. labiosa (Kreutz.)(CR), Serapias vomeracea (CR) were found in the region.

This study aimed to evaluate the threat categories of the threatened orchids species at both national and regional scales. In this context, threat factors were determined through field observations, including collection of orchid tubers, presence of roads and fields, transportation, residential and recreational activities, fires.

\section{Materials and Methods}

The research area was located in the Eastern Mediterranean Region between 34048'-37012' northern latitudes and 36059'-36019' eastern longitudes. The area stands within the provincial borders of the cities of Adana (Karaisalı, Kadirli, Pozantı, Sarıçam), Hatay (İssume, Kaşmer), Kahramanmaraş (Başkonuş, Darovası, Tömek, Uzundağ) and Mersin (Çamlıyayla, Gülnar, Erdemli, Mut, Silifke, Tarsus), and is located within the C4, C5 and C6 grids of Davis Grid System (Figure 1). 


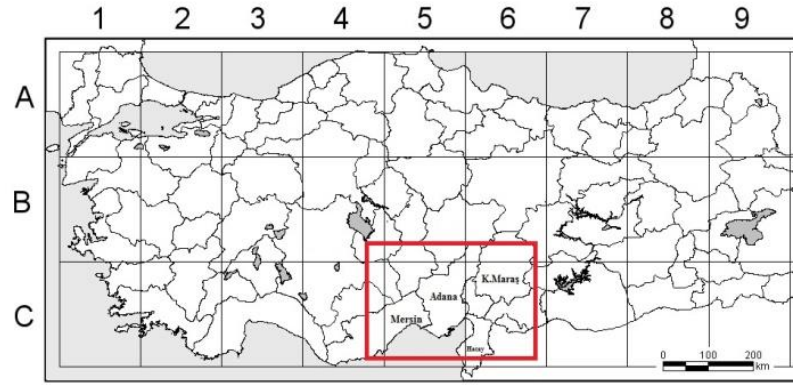

Figure 1 Research Area

Observation plots were selected considering the representativeness for the Eastern Mediterranean Region in terms of orchid species diversity and being dispersed into different altitude zones. 20 of observation plots were chosen in this context from the Mediterranean zone (0$200 \mathrm{~m}), 18$ plots were from the sub-Mediterranean (201$1300 \mathrm{~m})$, and 6 plots were from the Mediterraneanmontane (1301-1800 m) zones (Sandal, 2009).

To determine the threat categories of the observed orchid species at a regional scale, threat points obtained from the averages of the numbers of individuals in the observation plots were weighted by multiplying by two considering the fact that the most efficient criterion was the size of the local population.

\section{Results and Discussion}

Some of endemic and non-endemic plant taxa within the flora of Turkey are under various anthropogenic pressures, some are experiencing difficulties in sustaining their generations as a result of these factors. These anthropogenic factors included industrialization, urbanization, expansion of agricultural areas, excessive grazing, tourism, exports, harvesting from the natural sources for domestic use, reclamation of barren lands, agricultural practices and chemical contamination, reforestation and fire.

The status of Turkey's endangered rare and endemic plants were evaluated on the basis of the threat categories in the "Red Data Book of Turkish Plants" prepared by Ekim et al. (2000) according to the IUCN Species Survival Commission's "IUCN Red List Categories" version 2.3. In the version 3.1 of the same publication published later in 2001, the threat categories of rare and endemic plants were re-evaluated and amended. As a result of this, sub-categories LR (Lower risk), lc (least concern) and cd (Conservation dependent) were modified and subsumed under LC (least concern) and NT (near threatened). Finally in 2006, the Red Data Book of Turkish Plants was updated within the context of projects, "Capacity Building in the Field of Environment for Turkey" and "Components within the context of the nature of the Twinning Project", which were conducted by the General Directorate of Nature Conservation and National Parks.

We assumed that the threat conditions of plant species might be different at local, regional and global scales due to possible differences in the efficiency of pressure factors. Therefore, to control the categories defined by the IUCN at regional and local scales, more research to delineate the boundaries clearly are needed. It is reasonable for a species to be assigned to different categories at the national scale and the regional scale, depending on its population characteristics and environmental factors which threat this species. So, the success of a proposed protection plan for a species depends on detailed information on the categories of danger of populations which spread across different geographic units.

Butler (1986), Rossi (1988) with Kreutz (1998-2009) were used in the identification of orchid species. Davis (1984) and Ekim et al. (2000) was used in the determination of the distribution areas of orchid species in Turkey. The threat categories of plant taxa were determined by scanning resources related to the IUCN Red List categories and the Criteria Version 3.1. Those newly recorded for C5 grid were marked with (*) in Table 1. Davis (1984) volume eight was used to determine new records of taxa.

- The existence ratios of the orchid species detected in the 44 observation plots were sorted and ranked according to the following scale.

- The average of the number of individuals belonging to the orchid species recorded in the observation plots in the three-year period were evaluated according to the scale given below.

- Turkey was divided into 27 grid squares according to Davis (1984) grid system. The existence ratios of the orchid species recorded in the research area were evaluated according to the limits specified below by calculating their distributions in Turkey.

- Three points were given if the plant species is only seen in solely one bio-climatic belt according to the distribution of species along bio-climatic zonation. 2 points were given if it is seen in 2 and finally 1 point was given if it is seen in 3 belts.

- Considering the state of orchid species of being endemic, 0 threat point was given to the non-endemic orchid species, while 1 point was awarded to the species endemic to Turkey

The main floristic components within the boundaries of the study area are: Cephalantherakurdica Bornm, $C$. longifolia, C. rubra L., Comperiacomperiana, Dactylorhizaiberica (Willd.), D. osmanica, Epipactishelleborine, Himantaglossum affine, Limodorumabortivum, Ophrysapifera, O. bornmuelleri M. Schulze ,O. cilicica Schlechter, O. ferrum-equinum Desf., O. fusca Link., O. holoserica, O. isaura Renz \& Taubenheim, O. lutea Cav., O. mammosa Desf., O. reinholdii $H$. Fleischm, O. umbilicata Desf., O. vernixia Brot., Orchis anatolica Boiss., O. collina Banks\&Solander, O. coriophora L., O. italica Poiret., O. laxiflora Lam., O. mascula L., O. palustris Laco., $O$. papilionaceae L., O. punctulata Lindley., O.simia Lam., $O$. spitzeli Koch., O. tridentata Scop. and Serapias vomeracea. The data reported by Yilmaz (2001) were used for the classification of bio-climatic zonesas one of the evaluation criteria for the threat categories. 
The number of individuals for each orchid species in the observation plots was recorded periodically during three years. The species assigned to the threat categories in the IUCN sources (CR, EN, VU, NT, LC) were determined. Five criteria were developed for the determination of regional scaled threat categories for orchid species recorded in the observation plots. These criteria are the rate (frequency) of existence in the entire research area, the average number of individuals in the plots, geographical distribution in Turkey, distribution in bioclimatic zones and the status of endemism. These criteria were evaluated with a scoring system taken into account the determined limits as presented below, and corresponding values and limits were summarized in Table 1 .

The threat points for the recorded orchid species were calculated according to the five evaluation criteria explained in the method section and were given in Table 2. According to these scores, the threat categories at a regional scale were proposed and compared with current IUCN categories.

Table 1 The values and limits of threat rating, existence ratios, occurrence in 27 grid squares of Turkey, and average number of individuals used in the study*

\begin{tabular}{c|ccc}
\hline Threat rating & Existence ratio (\%) & Occurrence in Turkey in 27 Grid squares & Average Number of Individuals \\
\hline 1 & $36-44 \%$ & $22-27$ & $61-87$ \\
2 & $26-35 \%$ & $15-21$ & $36-60$ \\
3 & $13-25 \%$ & $8-14$ & $16-35$ \\
4 & $1-12 \%$ & $1-7$ & $1-15$ \\
\hline
\end{tabular}

Table 2 Comparison of the regional threat categories, assigned according to the threat ratings, with current IUCN threat categories of recorded orchid species

\begin{tabular}{|c|c|c|c|c|c|c|c|c|c|}
\hline \multirow{2}{*}{$\begin{array}{c}\text { Sequence } \\
\text { number }\end{array}$} & \multirow{2}{*}{ Taxa } & \multicolumn{5}{|c|}{ The criteria and threat points } & \multirow{2}{*}{ Total } & \multirow{2}{*}{$\begin{array}{c}\text { IUCN } \\
\text { category }\end{array}$} & \multirow{2}{*}{$\begin{array}{c}\text { Suggested } \\
\text { category }\end{array}$} \\
\hline & & $\mathrm{C} 1$ & $\mathrm{C} 2$ & $\mathrm{C} 3$ & $\mathrm{C} 4$ & $\mathrm{C} 5$ & & & \\
\hline 1 & Cephalanthera kurdica & 3 & 6 & 4 & 2 & 0 & 15 & VU & VU \\
\hline 2 & Cephalanthera longifolia & 3 & 8 & 4 & 3 & 0 & 18 & EN & EN \\
\hline 3 & Cephalanthera rubra & 4 & 8 & 4 & 3 & 0 & 19 & $\mathrm{CR}$ & $\mathrm{CR}$ \\
\hline 4 & Comperia comperiana & 4 & 8 & 4 & 3 & 0 & 19 & - & $\mathrm{CR}$ \\
\hline 5 & Dactylorhiza iberica Willd. & 4 & 8 & 4 & 3 & 0 & 19 & - & $\mathrm{CR}$ \\
\hline 6 & Dactylorhiza osmanica & 3 & 8 & 3 & 1 & 1 & 16 & - & VU \\
\hline 7 & Epipactis helleborine & 4 & 6 & 4 & 2 & 0 & 16 & EN & VU \\
\hline 8 & Himantaglossum affine & 4 & 8 & 4 & 3 & 0 & 19 & - & $\mathrm{CR}$ \\
\hline 9 & Limodorum abortivum & 4 & 6 & 4 & 3 & 0 & 17 & VU & $\mathrm{EN}$ \\
\hline 10 & Ophrys apifera & 4 & 6 & 4 & 3 & 0 & 17 & VU & EN \\
\hline 11 & Ophrys bornmuelleri & 2 & 6 & 4 & 2 & 0 & 14 & LR & NT \\
\hline 12 & Ophrys cilicica & 4 & 8 & 4 & 2 & 0 & 18 & - & $\mathrm{EN}$ \\
\hline 13 & Ophrys ferrum-equinum & 4 & 8 & 4 & 3 & 0 & 19 & - & $\mathrm{CR}$ \\
\hline 14 & Ophrys fusca & 4 & 6 & 4 & 3 & 0 & 17 & - & EN \\
\hline 15 & Ophrys isaura* & 3 & 2 & 1 & 2 & 1 & 9 & EN & $\mathrm{LC}$ \\
\hline 16 & Ophrys holoserica & 4 & 8 & 4 & 3 & 0 & 19 & VU & CR \\
\hline 17 & Ophrys mammosa & 4 & 8 & 4 & 3 & 0 & 19 & - & CR \\
\hline 18 & Ophrys reinholdii & 4 & 8 & 4 & 3 & 0 & 19 & VU & $\mathrm{CR}$ \\
\hline 19 & Ophrys umbilicata & 3 & 6 & 4 & 2 & 0 & 15 & - & VU \\
\hline 20 & Orchis italica & 4 & 8 & 4 & 3 & 0 & 19 & - & CR \\
\hline 21 & Orchis collina & 4 & 8 & 4 & 3 & 0 & 19 & - & CR \\
\hline 22 & Orchis coriophora L. & 4 & 8 & 4 & 2 & 0 & 18 & - & $\mathrm{EN}$ \\
\hline 23 & Orchis anatolica & 1 & 2 & 4 & 1 & 0 & 8 & - & $\mathrm{LC}$ \\
\hline 24 & Orchis laxiflora & 4 & 6 & 4 & 3 & 0 & 17 & - & $\mathrm{EN}$ \\
\hline 25 & Ophrys lutea & 4 & 6 & 4 & 2 & 0 & 16 & EN & VU \\
\hline 26 & Orchis mascula & 4 & 6 & 4 & 3 & 0 & 17 & - & $\mathrm{EN}$ \\
\hline 27 & Orchis simia & 4 & 8 & 4 & 3 & 0 & 19 & VU & $\mathrm{CR}$ \\
\hline 28 & Orchis spitzeli & 4 & 8 & 4 & 3 & 0 & 19 & - & CR \\
\hline 29 & Orchis palustris & 4 & 4 & 4 & 2 & 0 & 14 & - & NT \\
\hline 30 & Orchis papilionaceae & 4 & 8 & 1 & 3 & 0 & 16 & - & VU \\
\hline 31 & Orchis punctulata & 4 & 8 & 4 & 2 & 0 & 18 & - & EN \\
\hline 32 & Orchis tridentata & 4 & 8 & 4 & 2 & 0 & 18 & - & EN \\
\hline 33 & Ophrys vernixia* & 3 & 6 & 4 & 2 & 0 & 15 & - & VU \\
\hline 34 & Serapias vomeracea & 4 & 6 & 4 & 3 & 0 & 17 & - & EN \\
\hline
\end{tabular}

VU: Vulnerable, CR:Critically Endangered, EN:Endangered, NT:Near Threatened, LC:Least Concern, LR:Lower Risk 
Whilst 34 orchid species determined in the research according to the IUCN resources, the threat categories were reported only for 12 species. When the categories given according to the IUCN resources are taken into consideration, threat categories at regional scale determined in this study showed differences. Limodorum abortivum, Ophrys apifera, O. holoserica, O. reinholdii and $O$. simia were evaluated under higher categories, Epipactis helleborine, Ophrys isaura, O. bornmuelleri and $O$. lutea were evaluated under lower ones while Cephalanthera rubra, C. Longifolia and C. kurdica were evaluated under equivalent categories.

According to the findings of this study, Cephalanthera rubra has the highest priority amongst all the species that should be conserved at the regional scale with the highest score, CR (19 points) as stated in the IUCN. Thus, this species was assigned to the same category. Ophrys holoserica, O. reinholdii and Orchis simia were assigned to the highly vulnerable CR category with the score of 19 while they were in the vulnerable category (VU) in the IUCN. Ophrys holoserica included in the vulnarable (VU) category in the "Red Book of the Plants of Turkey" was identified only in the three plots of the experimental plots (Kahramanmaraş-Tömek, Uzundağ Kabakyeri, MutKayrak). Orchis papilionaceae fell into the VU category as it was in the study conducted by Vukovic et al. (2011).

Such functional use of plants led to the development of ornamental plants market, which finally has reached a point which is economically significant. In 145 countries around the world, the cultivation of ornamental plants is carried out on a total area of 220,000 ha, and the trade volume of ornamental plants is around \$50 billion USD. Orchids are the most important flowers in this market. For this, most of the orchid species are collected from nature. For protecting the natural populations of rare and endemic plant species, the determination of natural populations, recordings and propagations are very important (Guney et al., 2016).

Ljubičić (2006) studied the rare and threatened vascular plants of the island of Pag according to 1994 and 2005 Red Books. Based on 2005 Red Book, the flora of the island of Pag includes 33 threatened taxa (species and subspecies). Eight of them are critically endangered (CR), seven are in the endangered category $(\mathrm{EN})$ and 18 taxa belong to the vulnerable category (VU). Orchid species and categories were recorded as follows, Ophrys bertolonii Moretti (VU), O. fuciflora Haller (VU), O. sphegodes Mill. (VU), Orchis coriophora L. (VU), Orchis provincialis Balb.(VU), Orchis purpurea Huds. E (VU), Orchis simia Lam. (VU), Orchis tridentata Scop. (VU).

Cephalanthera longifolia, is in the category of EN and as a-protected species by the IUCN, and it was assigned to the same category after being evaluated in the category of species in need protection with 17 points (IUCN, 2011). Jalal (2012), reported that it has been found widely in Himalayas.

Ophrys apifera, is in the LC category in the IUCN while it is in the EN category according to Vukovic et al.(2011) in parallel to this research. Orchis coriophora is in the EN category according to this research while it is not included in the threat categories of the IUCN. This species is in the VU category according to the research of Vukovic et al. (2011).

While Epipactis helleborine was in the category of EN in the IUCN, it was assigned to the vulnerable category having received 16 points following to our regional research findings. This species was found in different categories in various resources for example, in $\mathrm{CR}$ category in England (IUCN, 2011), in LC category in Britain (IUCN, 2005) and widely found category on Himalayas according to (Jalal, 2012).

While Limodorum abortivum was in the category of vulnarable (VU) in the IUCN, it was assigned to the category of EN with 17 points according to our evaluation.

Ophrys isaura, an endemic orchid species to Turkey, was assigned to the LC category having received 9 points while it was in EN category according to the IUCN; it is reported that only in the $\mathrm{C} 4$ grid and endemic to Turkey. According to the results of this research, this species was recorded in C5 square and can be considered as a new record. Recorded localities are; the west of Menekşe village, the cemetery of Cukurova University, Çamliyayla (Kaburgediği), Horticultural Research Institute of Erdemli, in Gülnar (Kocaoluk Kardak and Çifteli locations) and in Karaisalı regions (Kelköy cemetery) which fall into the sub-Mediterranean and Mediterranean climatic zone.

Ophrys isaura was found in 11 plots and was considered to be abundant in terms of its number of individuals. This event led the threat assessment to be lowered down. Thus, it is understood that the distribution area of this species in Turkey is possibly wider. On the other hand, the other species Ophrys vernixia, which is a new record for the province of Adana, was assigned to the category VU.

While Ophrys bornmuelleri was in the category of LR in the IUCN, it was assigned to the NT category since it has received 14 points in our research. This species was found widely distributed in the research area. While Orchis simia was in the category of VU in the IUCN, it was assigned to the CR category with 19 points according to our study.

The most widespread two species in our study area are Orchis isaura and Ophrys anatolica. The IUCN has not reported any information on Ophrys anatolica. It was evaluated in LC category because of 8 points assigned to it. It was found in 15 grids in Turkey (A2, A3, A5, B1, B2, B8, C1, C2, C3, C4, C5, C6, C7, C8, C9), while was found only in three grids in our study, in Çamliyayla (Kaburgediği), Erdemli (Alata Horticultural Research Institute), Gülnar (Çifteli location, KocaolukKardak location), İskenderun (Kaşmer village), Kadirli (KaratepeAslantaş National Park), Kahramanmaraş (Kabakyeri-Uzundağ location), Mut (Sand Quarry, Kayrak Village,Taşlı hill), Niğde (Karagümüş 1-2), Pozantı (Gülek Strait)), Silifke (Göksu Delta) and Tarsus (Muhat village, Sağlıklı village, cemetery of Sucular village). It grows in the Mediterranean-montane, the sub Mediterranean and the Mediterranean climate zones. 
Comperia comperiana, Dactylorhiza iberica, Himantaglossum affine, Ophrys ferrum-equinum, $O$. mammosa, Orchis collina, O. italica and O. spitzeli were rarely found in the observation plots. The IUCN did not report any threat category for these species. These species were assigned to the CR category with 19 points that they received in the study. Cephalanthera kurdica was determined to be in the VU category as noted by the IUCN.

It was demonstrated that six orchid species grow in the Mediterranean-mountain belt, 20 in the subMediterranean belt and 23 in the Mediterranean belt. The number of orchid species growing in the MediterraneanMontane Belt is much lesser than the other belts and only one unique species (Orchis punctulata) has been determined to be growing in this belt. 34 species of orchid determined by this study were regionally evaluated in the categories of CR (12 species), EN (11 species), VU (7 species), NT (2 species) and LC (2 species).

This study was conducted in 44 observation plots in the Eastern Mediterranean region. It was assumed that the number of individuals is the most important factor in terms of presenting data on the population. Although the data, being limited to the 44 plots restricted to the research area, prevent us from making some generalizations; recommendations were presented to allow re-determination of conservation status of the species identified within the boundaries of our research area. The average number of individuals in the plots chosen within the research area provided a comparative approach regarding the population among the taxa.

In the light of all these evaluations, it is believed that there is a need for insitu protective measures for some species. These species are Cephalanthera rubra, Comperia comperiana, Dactylorhiza iberica, Himantaglossum affine, Ophrys ferrum-equinum, Ophrys holoserica, Ophrys mammosa, Ophrys reinholdii, Orchis collina, Orchis italica, O. simia and O. spitzeli. A few numbers of individuals of these identified orchid species is thought to be an indicator of destruction factors such as collection, while it might have sourced from reproductive physiology as well.

Considering the research results, it seems that the total of species in categories CR, EN and VU (21) are higher than that of the other two belts. Plant species in these categories were determined to be 18 in the SubMediterranean belt, while only five were determined in the Mediterranean-Montane Belt. However, when species with limited distribution in only one climate belt are concerned, the Mediterranean zone in capsulated 11 species in total, including CR, EN and VU categories being six, four and one, respectively. On the contrary, no species, assigned to one of these categories and distributed in the Mediterranean-Montane Belt, were determined while only the species that was included in five CR categories existed in Sub-Mediterranean Belt.

This proves the argument that there is a high-level threat factor on the orchid species in the Mediterranean zone, which is considered to be dominant starting from the sea-level and reaching up to $250 \mathrm{~m}$ (ASL) due to extensive use due to accessibility. Necessary measures should be taken against these threat factors to prevent these species to be assigned to the category of CR and to fall into EX status.

\section{Conclusion}

The aim of landscape architecture is to provide an inhabitable environment. Landscape architects have carried out studies from the past to present for the environmental conformity and objective for the design of all spaces. Meanwhile, the design studies of landscape architects should be sustainable (Güngör, 2017).

It could be argued that environmental factors are quite influential on the grow of the orchid species which are almost naturally found in every region in Turkey. It was also determined that species included in various threat categories are under dense threat due to anthropogenic effects and only a limited number of species are welldistributed and profoundly existed in groups. The categories of these species at regional scale were proposed to be lower with respect to the categories determined by the IUCN. Distribution area of the species in the region should be determined more accurately. The threat categories of species should be evaluated periodically. Locals engaged in collecting the plant should be well-trained. Training should be provided and supported with visual and printed publications and only skilled people should train the trainees to achieve and increase the public awareness and participation to the biodiversity conservation.

\section{References}

Butler KP, 1986. Orchideen. Die Wirldwachsenden Arten und Unterarten Europas, Vorderasiens und Nordafrikas. Gesamtherstellung Mohndruck Graphische Betriebe Gmbh, Gütersloh, Germany. 287p.

Çakan H, Y1lmaz KT, Düzenli A 2005. First Comprehensive Assessment of the Conservation Status of the Flora of Çukurova Deltas, Southern Turkey. Oryx Vol 39 (1): 17-21.

Çetin M, 2016. Peyzaj Planlamada Biyoklimatik Konfor Alanların Belirlenmesi: Cide Kıyı Şeridi Örneği. Türk Tarım - Gıda Bilim ve Teknoloji Dergisi, 4(9): 800-804, 2016

Davis PH, 1984. Flora of Turkey and The East Aegean Islands. Edingburg University Pres. Vol: 8.

Ekim T, Koyuncu M, Vural M, Duman H, Aytaç Z, Adıgüzel N, 2000.Türkiye Bitkileri Kırmızı Kitabı (Eğrelti ve Tohumlu Bitkiler). Red Data Book of Turkish Plants. Ankara. S.246.

Guney K, Cetin M, Sevik H, Guney KB. 2016. Effects of Some Hormone Applications on Germination and Morphological Characters of Endangered Plant Species Lilium artvinense L. Seeds, New Challenges in Seed Biology - Basic and Translational Research Driving Seed Technology, Dr. Susana Araújo (Ed.), InTech, Chapter 4: 97-112

Güngör S. 2017. The Examination of Environmental Design Principles in Public Institutions in the Example of the Current Landscape Design of Konya Courthouse. Turkish Journal of Agriculture - Food Science and Technology, 5(2): 176-181, 2017.

Horak D. 2004 Orchid sand How They Grow. Brooklyn Botanic Garden. http://www.bbg.org

IUCN. 2005 IUCN SSC Red List Programme Committee. Guidelines for Application of IUCN Red List Criteria at Regional Levels, Available at: www.iucn.org/webfiles/ doc/SSC/RedList/pdf_(on 30th of June, 2015). 
IUCN. 2008. Red List of Threatened Species. SSC African Rhino Specialist Group.

IUCN. 2011 www.arkive.org. IUCN RedList. http://www.iucnredlist.org

Jalal JS. 2012 Status, threats and conservation strategies for orchids of western Himalaya, India. 4(15): 3401-3409.

Kreutz CAJ. 1998 Die Orchideen der Türkei (Beschreibung, Ökologie, Verbreitung, Gefährdung, Schutz). Cip-Gegevens Koninklijke Bibliotheek, Den Haag. Netherlands. 766 P

Ljubičić L, Britvec M 2006. Rare And Threatened Plants of The Island of Pag Agronomsk1 Glasnik 1/2006.

Rossi W. 1988. Orchids. Simon \& Schuster Inc. Rockefeller Center.1230 Avenue of the Americas. New York. 255p.
Sandal G. 2009. Doğu Akdeniz Bölgesi’nde Doğal Salep Türlerinin Saptanması ve Mikorizaların Belirlenmesi Üzerine Araştırmalar. Ç.Ü. Peyzaj Mim. Böl. Doktora Tezi.

Vukovic N, Brana S, Mitic B. 2011. Orchid diversity of the cape of Kamenjak (Istria, Croatia). Acta Bot. Croat. 70 (1): 23-40p.

Yeşilyurt EB, Akaydın G. 2012. Endemic plants and their threat categories of Muğla province (Turkey). Hacettepe J.Biol\&Chem, 40 (2): 195-212

Yılmaz KT. 2001. Akdeniz Doğal Bitki Örtüsü. Ç.Ü. Zir. Fak. Peyzaj Mimarlığı Bölümü. Ç.Ü.Z.F.Genel Yayın No:141. Ders Kitaplar1 Yayın No: B-13 Adana. 179 S. 